\title{
Exposure of Vicia faba to sulcotrione pesticide induced genotoxicity
}

\author{
Chaima Sta ${ }^{\mathrm{a}, \mathrm{b}}$, Gérard Ledoigt ${ }^{\mathrm{a}, *}$, Ezzeddine Ferjani $^{\mathrm{b}}$, Pascale Goupil ${ }^{\mathrm{a}}$ \\ a Clermont Université, Université Blaise Pascal, UMR 547 PIAF, BP 10448, F-63000 CLERMONT-FERRAND, Campus Universitaire des Cézeaux, 24 Avenue des Landais, \\ 63177 Aubière cedex, France \\ ${ }^{\mathrm{b}}$ Laboratoire de Physiologie et Génétique des Plantes à Intérêt Agronomique, Faculté des Sciences de Bizerte, Université de Carthage, 7021 Jarzouna, Tunisia
}

\section{A R T I C L E I N F O}

\section{Article history:}

Received 27 July 2011

Accepted 10 February 2012

Available online 22 February 2012

\section{Keywords:}

Chromosomal aberrations

Genotoxicity

Herbicide

Micronuclei

Root tips

Sulcotrione

\begin{abstract}
A B S T R A C T
Potential genotoxicity of sulcotrione 2-(2-chloro-4-(methylsulfonyl)benzoyl)-1,3-cyclohexanedione, a selective triketonic herbicide was evaluated on Vicia faba seedlings in hydroponic culture conditions. Sulcotrione $\left(10^{-5}, 10^{-4}\right.$ and $\left.2 \times 10^{-4} \mathrm{M}\right)$ treatments for $45 \mathrm{~h}$, caused a dose dependent increase in micronuclei frequencies in root meristematic cells. Cytological analysis of root tips cells showed aneugenic effects of the sulcotrione on the plant root meristems. Sulcotrione induced chromosomal alterations at the lowest concentration used $\left(10^{-5} \mathrm{M}\right)$ when incubated for $42 \mathrm{~h}$, indicating the potent mutagenic effect of this element. This is the first report for the genotoxicity of such a sulcotrione herbicide.
\end{abstract}

(c) 2012 Elsevier Inc. All rights reserved.

\section{Introduction}

Sulcotrione, chemically defined as 2-(2-chloro-(4-methylsulfonyl)benzoyl)-1,3-cyclohexanedione (Fig. 1) is a recent triketone herbicide used to control a wide range of grasses and broad leaf weeds in corn crop yields and is proposed as an atrazine substitute. In target plant species, the action of this herbicide (Fig. 1) consists in the inhibition of the enzyme 4-hydroxyphenyl pyruvate dioxygenase (p-HPPD) $[1,2]$ leading to strong bleaching effects accompanied by a decrease in chlorophyll and carotenoid levels as well as by a massive accumulation of phytoene $[3,4]$, necrosis and death of sensitive plants [5]. Sulcotrione is an herbicide applied at a rate of 450 gha $^{-1}$ at maize post-emergence. It is absorbed by the leaves and also by the roots [6,7]. Triketones herbicides inhibit the chain of photosynthetic electron transfer that is blocking a vital mechanism of energy production within the plant [8]. The application of these active ingredients should be at an early stage of development of dicotyledonous targeted to be fully effective and lead to their removal. The triketones act by foliar and root channels and have an action antigerminative to control weeds after treatment.

Cellular metabolism of sulcotrione produces CMBA (2-chloro4-methylsulfonylbenzoic acid) in plants and hydroxysulcotrione in mammals. Sulcotrione is persistent for a short time but mobile $[6,7,9]$. The photodegradation of sulcotrione leads to a stable toxic

\footnotetext{
Abbreviations: MCN, micronucleus; MH, maleic hydrazide; MI, mitotic index.

* Corresponding author. Fax: +33 473407942 .

E-mail address: gerard.ledoigt@univ-bpclermont.fr (G. Ledoigt).
}

intermediate product that is prevented by using grape natural products [10-14].

Extensive use of herbicides in agriculture and potential carcinogenicity strongly emphasize the need to extend the genotoxic evaluation of these compounds by using different assays. Mitotic root meristems of Vicia faba have been pioneer cytogenetic materials for genotoxicity studies of physical and chemical agents since the early 1930s. It has a low chromosome number $(2 n=12)$, making it suitable for cytogenetic studies. The formation of micronuclei $(\mathrm{MCN})$ in root tips has been widely described and used as a bioassay for the evaluation of in vivo mutagenic effects of environmental pollutants on plants and animals [15-17]. The increased frequency of micronuclei was observed in many aquatic organisms exposed to various pollutants and indifferent cell types. Among biomarkers of exposure measured in animals, frequency of micronuclei was the one best correlated with the pollutant load in tissue. Several authors [18] concluded on the ability of this tool to reveal chronic contamination by persistent genotoxic agents in water and/or sediment at low concentrations.

Micronuclei can be composed of small chromosome fragments resulting from chromosome breaks caused by clastogenic activity. The failure of entire chromosomes to migrate during anaphase as a result of the aneugenic effects of genotoxic agents also can lead to micronucleus formation $[16,18-21]$.

In this study, we first reported the potentially genotoxic effects of sulcotrione for meristematic root cells of a Fabaceae species, $V$. faba. Cytological analysis of $V$. faba meristematic root cells showed the potential aneugenic effects of the pesticide on plant chromosomes. 
<smiles>CO[SH](C)(=O)c1ccc(C(=O)C2C(=O)CCCC2=O)c(Cl)c1</smiles>

Sulcotrione

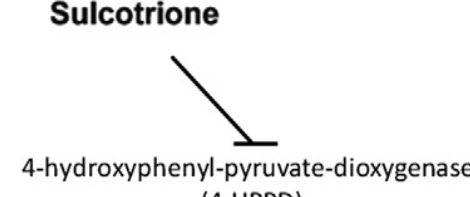

(4-HPPD)

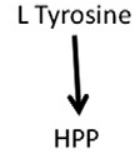

(4-hydroxyphenyl-pyruvate)

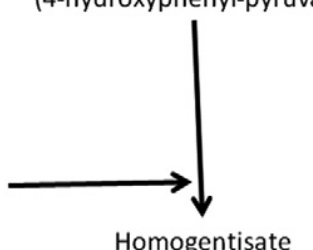

Fig. 1. Molecular structure of sulcotrione and its physiological herbicide effect on HPPD.

\section{Materials and methods}

\subsection{Plant material and chemicals}

Sulcotrione [2-(2-Chloro-4-(methylsulfonyl) benzoyl)-1, 3cyclohexanedione), 98.7\%, Mm 328.77] was purchased from Riedel de Haën (Pestanal ${ }^{\circledR}$, Saint-Quentin Fallavier, France).

Seeds of $V$. faba var. Aguadulce were surface sterilized with $10 \%$ sodium hypochloride, rinsed several times with distilled water and placed on moistened paper at $25^{\circ} \mathrm{C}$ for $4-5$ days, allowing them to germinate and transferred to a hydroponic support in the following nutrient solution $\left(\mathrm{pH} 7,3.9 \mathrm{mM} \mathrm{Ca}\left(\mathrm{NO}_{3}\right)_{2}, 6.5 \mathrm{mM} \mathrm{KNO}{ }_{3}, 2 \mathrm{mM}\right.$ $\mathrm{MgSO}_{4}, 0.9 \mathrm{mM} \mathrm{KH} \mathrm{PO}_{4}$ plus micro-nutrients: $90 \mu \mathrm{M}$ Fe-ethylene diamine tetra-acetic acid, $2.7 \mu \mathrm{M} \mathrm{MnSO}_{4}, 0.8 \mu \mathrm{M} \mathrm{ZnSO}_{4}, 4.5 \mu \mathrm{M}$ $\mathrm{H}_{3} \mathrm{BO}_{3}, 4 \mu \mathrm{M} \mathrm{CuSO}{ }_{4}$ and $\left.2.0 \mu \mathrm{M} \mathrm{Mo} \mathrm{MO}_{24}\left(\mathrm{NH}_{4}\right)_{6}\right)$ as described by Souguir et al. [18]. Culture takes place in air-conditioned room under controlled conditions: $16 \mathrm{~h}$ light/8 h darkness (Mazdafluor Prestiflux) at a temperature $25 / 20^{\circ} \mathrm{C}$ and a relative humidity of $65 \%( \pm 5 \%)$.

\subsection{Plant treatments}

Once roots had reached a length of $2-3 \mathrm{~cm}$, additional concentrations of sulcotrione $\left(10^{-5}-2 \times 10^{-4} \mathrm{M}\right)$ were added to the hydroponic solution for $45 \mathrm{~h}$ at $25^{\circ} \mathrm{C}$ with a light/dark photoperiod of $16: 8 \mathrm{~h}$. All tests were repeated six times, using a negative control (SNS, containing no additional sulcotrione), and nutrient solution containing $4 \times 10^{-3} \mathrm{M}$ maleic hydrazide $(\mathrm{MH})$ as a positive control. $\mathrm{MH}$ is a herbicide known to be a mutagenic and clastogenic agent [22]. Maleic hydrazide is chemically defined as 1,2-dihydro-3,6pyridazinedione, an uracile isomer, and a herbicide used in agriculture. It is known for its ability to induce micronuclei and chromosomal aberrations in $V$. faba [22].

$V$. faba root tip micronucleus test is one of the most employed plant genotoxicity assays, and has been used on various types of contaminated materials. A study of the effect of inorganic pollutants, such as cadmium, on bean roots in hydroponic culture, showed a highly significant difference in the mitotic index $(P<0.001)$ at $48 \mathrm{~h}$ of treatment [23], therefore we have chosen a similar period of treatment with pesticide. Elsewhere, $48 \mathrm{~h}$ exposure is more rapid and practical and was recommended for the standardization of this test [24].

\subsection{Microscope observations}

Root tips (meristem zones) were cut and placed overnight in the dark in the Carnoy fixation solution containing ethanol and glacial acetic acid (3:1) at $4{ }^{\circ} \mathrm{C}$, and then stored in $70 \%$ ethanol. Root tips were rinsed with distilled water and hydrolyzed with $1 \mathrm{~N} \mathrm{HCl}$ for $10 \mathrm{~min}$ as described by Souguir et al. [18]. The root cap was removed before squashing root tissues, and samples were stained with orcein. The slides were examined under Zeiss microscope. At least three slides were stained per replica and at least 1000 cells were scored from each slide. Therefore, the analysis was conducted on an average of 9000 cells per treatment. Micronucleus frequency was calculated from the number of micronuclei scored divided by the total cells scored, and expressed in terms of Micronuclei/1000 cells. The mitotic index (MI) was determined by counting the number of mitotic cells among the total amount of scored cells $(\sim 3000)$ per root. Mitotic index (MI) and micronuclei (MCN) as well as aberrant mitosis frequencies were measured on the same slide.

\subsection{Pigment analyses}

Leaves were immersed in $80 \%$ acetone and then placed in the dark and cold. After $24 \mathrm{~h}$, the sample was crushed and then filtered through gauze. The residue was taken up in acetone $80 \%$. The filtrate was centrifuged for $5 \mathrm{~min}$ at $3000 \mathrm{rpm}$ speed. Pellets were taken up in $80 \%$ acetone solution till removing pigments. Pigment contents then were measured by absorbance at 450, 645 and $663 \mathrm{~nm}$. Concentrations of chlorophylls $\mathrm{a}$ and $\mathrm{b}$ and carotenoids were determined using equations of Mac Kinney [25] and Arnon [26]. Results were expressed as $\mathrm{mg} / \mathrm{g}$ fresh weight (FW).

\subsection{Statistical analysis}

All experiments were repeated six times. Before performing statistical analyses, data were checked for normality and homogeneity of variance, and were square root transformed [27], with the addition of 0.5 to all data in order to avoid zeros. Statistical analyses were performed using SYSTAT 11 software for Windows with a significance level of alpha $=0.05$. The Mitotic index (MI) and micronuclei (MCN) were compared using one-way ANOVA and the Dunnet multiple comparison procedure, control against treatments $\left(10^{-5}, 10^{-4}\right.$ and $2 \times 10^{-4} \mathrm{M}$ sulcotrione and $\left.\mathrm{HM}\right)$.

\section{Results}

Sulcotrione treatment of $V$. faba roots for $45 \mathrm{~h}$, showed root discoloration with increased doses that become darker with tannin increasing from $10^{-5}$ to $2 \times 10^{-4} \mathrm{M}$ sulcotrione. Different concentrations of sulcotrione $\left(10^{-5}-2 \times 10^{-4} \mathrm{M}\right)$, have reduced chlorophyll and carotenoid contents in plant leaves (Fig. 2).

Several usual pesticides (insecticides, fungicides and herbicides) were previously assayed for clastogenic and physiological activity using V. faba as an eukaryotic, whole-organism, test system [28]. In order to assess the genotoxic effects of sulcotrione, different concentrations were applied for a transient period of $45 \mathrm{~h}$ in hydroponic cultures. Mitotic index was decreasing along with sulcotrione concentration increase (Fig. 3A). Frequencies of cells with MCN in meristematic root tips plants are presented in Fig. 3B. The difference in the mean values among treatment groups are greater than would be expected by chance and there is a statistically significant difference for mitotic index $(F=114.78, P<0.001)$ and for micronucleus frequency $(F=45.150, P<0.001)$. Moreover multiple comparisons versus control group (Dunnett's method) shows significant differences $(P<0.05)$ between control and the four treatments.

Low micronucleus frequencies were detected in root tips of control plants. However, as expected, maleic hydrazide dramatically increased the frequency of micronuclei in root meristems as compared to control plants, showing that this herbicidal molecule can be used as a positive control for genotoxicity studies. Sulcotrione significantly enhanced the frequency of micronucleus formation in the root tips of $V$. faba. 

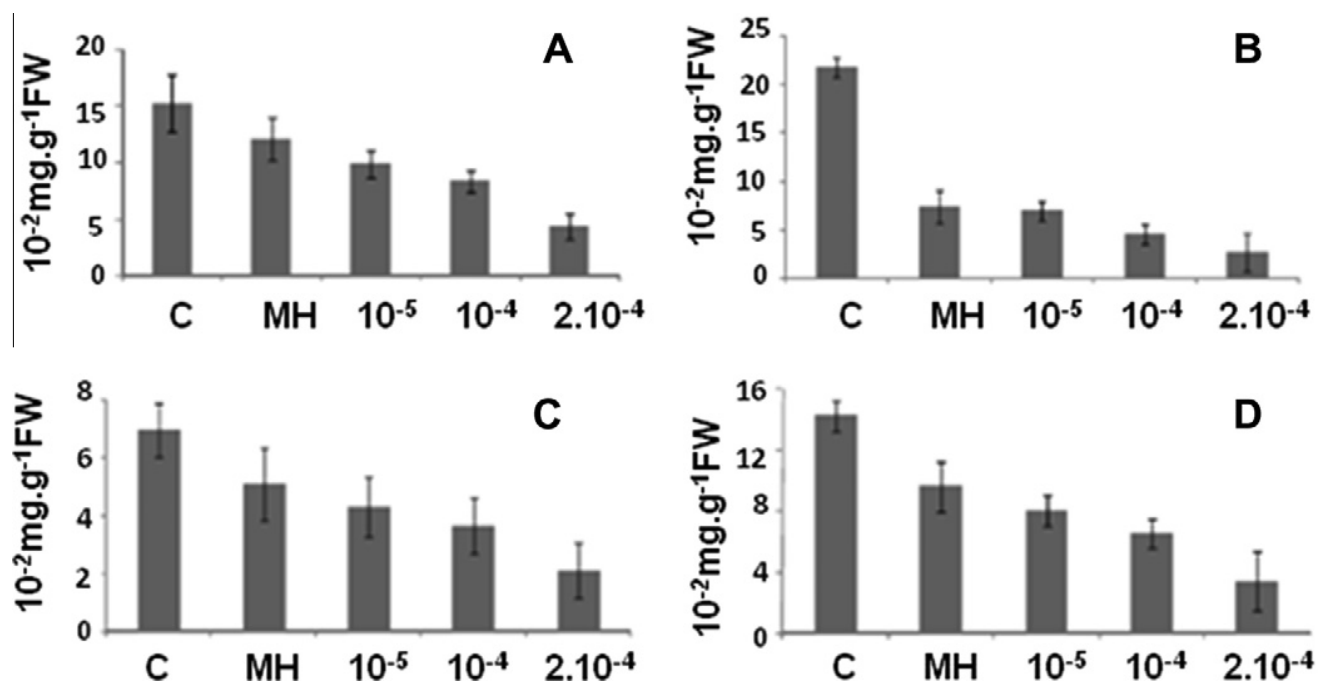

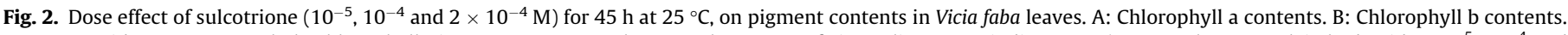

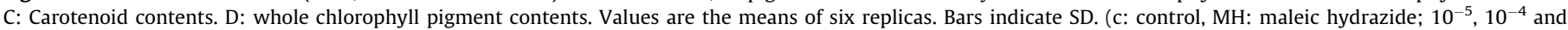
$2 \times 10^{-4} \mathrm{M}$ : sulcotrione concentrations).
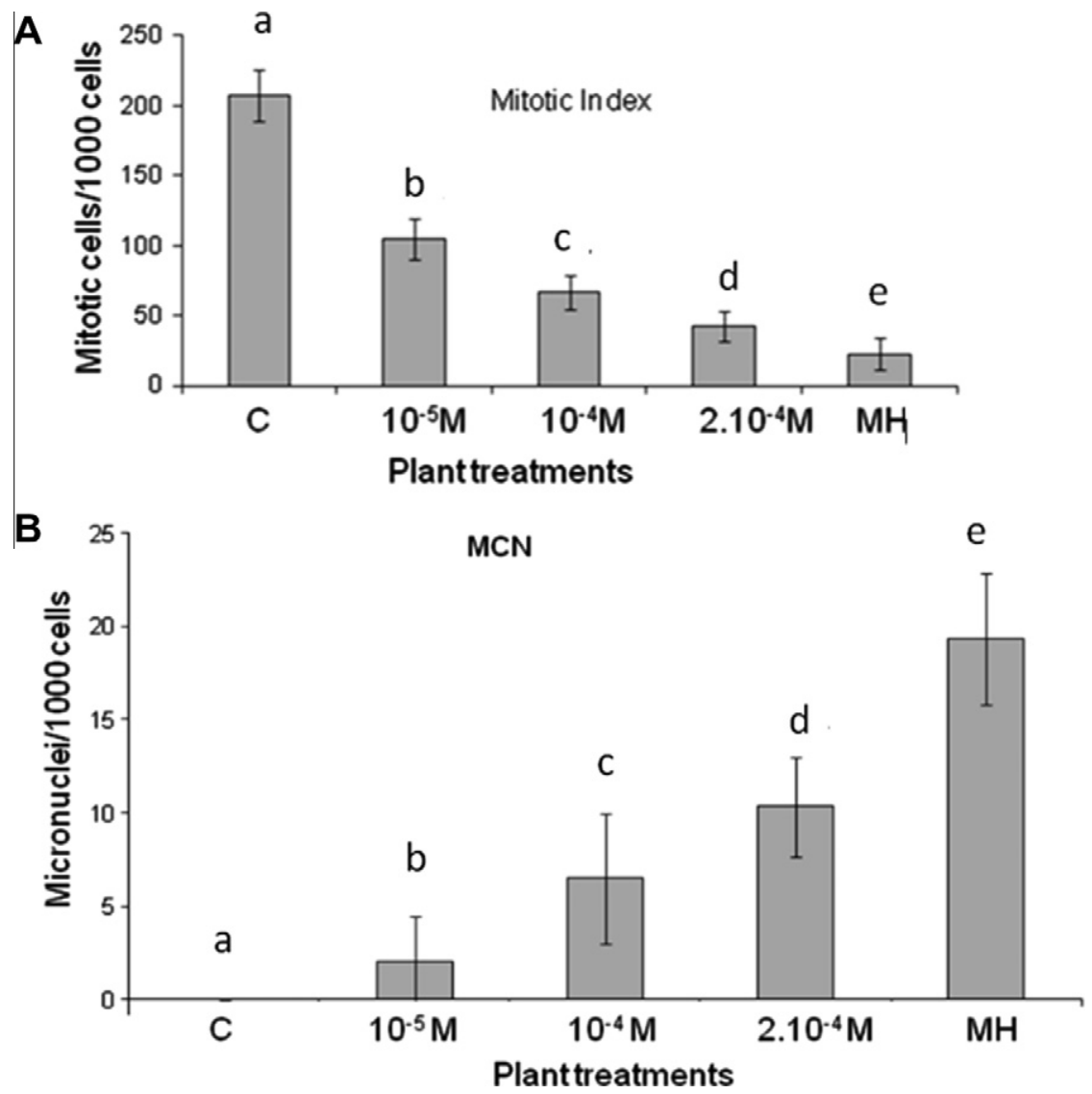

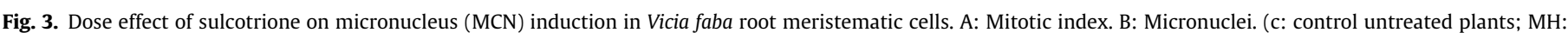

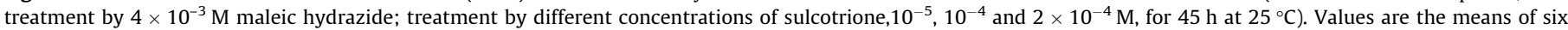

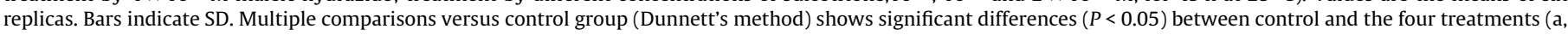
b, c, d, e, for each study).

Frequency of micronucleus formation was proportional to sulcotrione concentration added to the hydroponic solution. Micronucleus formation begins at $10^{-5} \mathrm{M}$ concentration of sulcotrione. The highest frequency of cells with micronuclei was detected with a $2 \times 10^{-4} \mathrm{M}$ sulcotrione treatment. Micrographies (Fig. 4A) show presence of micronuclei, usually one in a cell, following
$2 \times 10^{-4} \mathrm{M}$ sulcotrione treatments. Micronucleus (MCN) test showed that the sulcotrione was significantly genotoxic as compared to the negative control.

During the process of root cell mitosis, sulcotrione treatment allowed to show chromosomal abnormalities, mainly aneuploidies that are especially seen during anaphases (Fig. 4B). When com- 

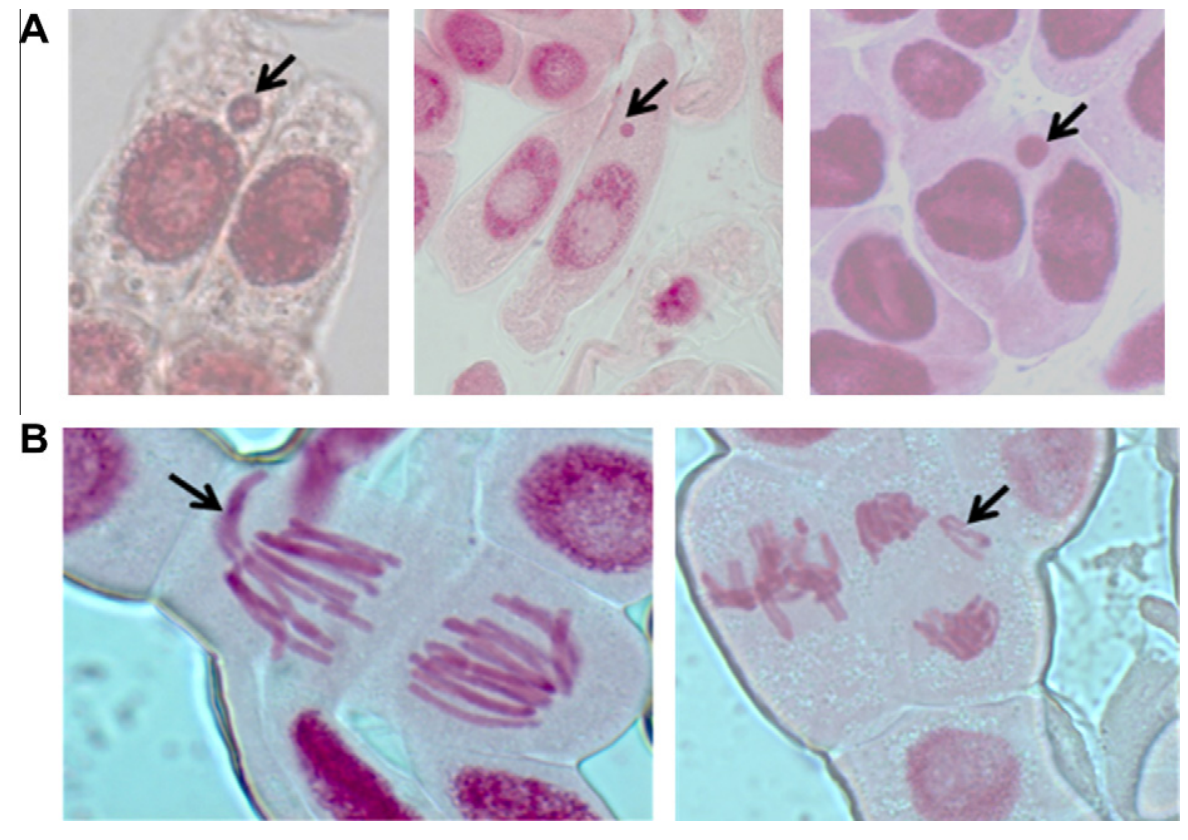

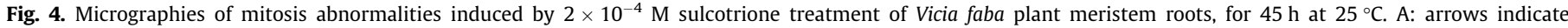
micronuclei in interphase meristematic cells. B: arrows indicate isolate chromosomes (aneuploidy) during mitotic anaphase of meristematic cells.

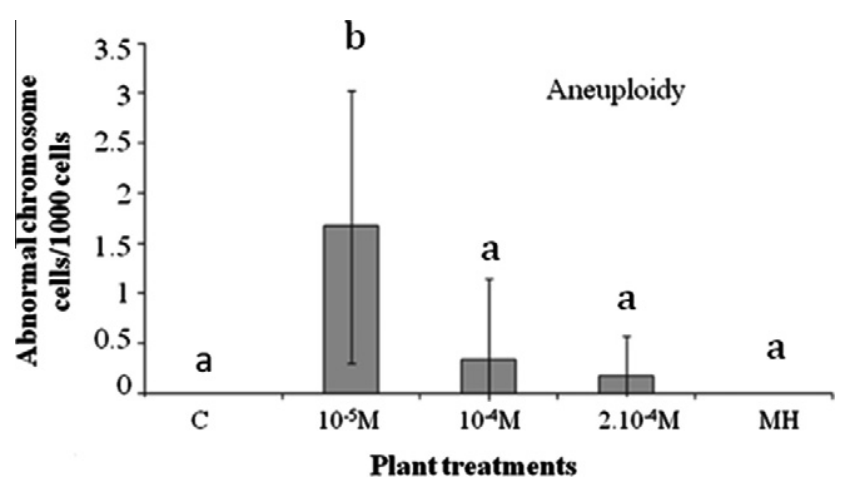

Fig. 5. Aneuploidy induction by sulcotrione treatments in Vicia faba root meristematic cells (c: control untreated plants; $\mathrm{MH}$ : treatment by $4.10^{-3} \mathrm{M}$ maleic hydrazide; treatment by different concentrations of sulcotrione, $10^{-5}, 10^{-4}$ and $2 \times 10^{-4} \mathrm{M}$, for $42 \mathrm{~h}$ at $25^{\circ} \mathrm{C}$ ). Values are the means of six replicas. Bars indicate SD. Multiple comparisons versus control group (Dunnett's method) shows significant differences $(P<0.05)$ between control and $10^{-5} \mathrm{M}$ sulcotrione treatment but not with the three other samples $(a, b)$.

Table 1

Percent of abnormal cells among mitotic cells.

\begin{tabular}{ll}
\hline Treatments & $\%$ Abnormal/mitotic cells \\
\hline Control & 0 \\
$10^{-5} \mathrm{M}$ sulcotrione & $1.603 \%$ \\
$10^{-4} \mathrm{M}$ sulcotrione & $0.498 \%$ \\
$2 \times 10^{-4} \mathrm{M}$ sulcotrione & $0.4 \%$ \\
$\mathrm{MH}$ & 0 \\
\hline
\end{tabular}

pared to control sample, chromosomal abnormalities are significantly and mainly observed for the lowest sulcotrione concentration $\left(10^{-5} \mathrm{M}\right)$ and are decreased with higher concentrations. ANOVA test displayed a statistically significant difference $(F=7.173, P<0.001)$ and multiple comparisons versus control group (Dunnett's method) shows significant differences $(P<0.05)$ between $10^{-5} \mathrm{M}$ sulcotrione treatment and the three other treatments, $a$ and $b$ notations (Fig. 5). Maleic hydrazide $\left(10^{-3} \mathrm{M}\right)$ did not cause any chromosomal abnormalities. The frequency of chromosomal aberrations is not correlated to mitotic index, at least for the low concentration $\left(10^{-5} \mathrm{M}\right)$ (Table 1$)$.

\section{Discussion}

The soil is a key compartment for the fate of pesticides in the environment; a large proportion of pesticides applied in the treatment of cultures comes ground, for direct application and/or leaching of the leaves. Sulcotrione and some other triketones, as mesotrione, have a similar behavior in soils and their long half-life varies from 5 to 65 days [29] which involves hydrolysis and biotransformation processes. The persistence in soil is also related to the adsorption of active ingredients on constituents of soils. It is more important in soils rich in organic [30,31] and $\mathrm{pH}$ dependent [32]. Sulcotrione herbicide is applied at $250-450 \mathrm{~g}$. ha ${ }^{-1}$ in maize post-emergence at the five to six leaf development stages. Sulcotrione is indeed moving in the soil until more than a month after application [7,9]. It is absorbed by leaves but also by roots. Water solubility of the product is $165 \mathrm{mg} \mathrm{L}^{-1}$ at $25^{\circ} \mathrm{C}$. Wilson and Foy [31] showed that sulcotrione adsorption was correlated to the soil organic matter content, in which sulcotrione persisted only briefly, but was mobile. Cherrier et al. [7] concluded that sulcotrione had a greater potential to leach than atrazine. The presence of residues in the whole soil profile resulted from the interaction of three factors; retention, solubility and persistence [7].

The lowest amount of sulcotrione, which showed genotoxicity in bean roots, was $10^{-5} \mathrm{M}$ in hydroponic conditions. For a similar culture surface, this herbicide amount represents only five times sulcotrione amounts usually spread per unit area in a field. However, it must take into account the mobility of the product in soil or in hydroponic condition, the presence of biotic and abiotic process in soil, transfer of the pesticide in aerial part of the plant to the ground, but also a possible local higher concentration of the product by sulcotrione solution runoff from different leaves of a plant. In addition, we must take into account the photo-destruction of sulcotrione which decreases the amount of herbicide available, but results in the production of inactive but toxic, stable derivative product $[13,14]$. 
Potential toxicity of sulcotrione, selective triketonic herbicide has been earlier [10] assessed using representative environmental microorganisms frequently used in ecotoxicology [12], since this species displays a great sensitivity to pollutants. Based on the dose-response slope values Allium and Vicia, were shown as efficient test systems for root micronuclei, yet, with a greater sensitivity of Allium roots [33]. Previously, nine common pesticides were assayed for clastogenic and physiological activity using $V$. faba as an eukaryotic, whole-organism, test system [28].

In addition to micronuclei ( $\mathrm{MCN}$ ) formation, cytological analysis of root meristems revealed drastic changes in the organization and morphology of chromosomes (Fig. 5). Highest micronucleus value was obtained with the highest sulcotrione concentration used $\left(2 \times 10^{-4} \mathrm{M}\right)$ (Fig. 3B). In contrast, chromosomal abnormalities decreased with higher sulcotrione concentrations, along with the mitotic index (Figs. 3A and 5). It was previously demonstrated relationships between chromosome abnormalities and MCN [18], but chromosome abnormalities were only seen in mitotic cells and micronuclei in interphase cells. Using another pesticide molecular type, it was shown that treatments with the insecticide dichlorvos on root meristems of $V$. faba, significantly decreased the mitotic activity and increased the frequency of chromosomal aberrations at the metaphase thus demonstrating both clastogenic and mito-depressive effects of DDVP on $V$. faba cells [34]. Using sulcotrione treatments, we have shown that the frequency of chromosomal aberrations is not correlated to mitotic index, at least for the lower concentration $\left(10^{-5} \mathrm{M}\right.$ ) (Table 1$)$. The clastogenicity effect of sulcotrione treatment thus is not linked to mitosis inhibition.

Quantitation of DNA breaks was often associated with the detection of micronuclei. Some authors note similar evolution of both types of damage [35-37]; others observed an increased frequency of MCN combined with a decrease or absence of a change in the number of breaks in DNA [38,39]. The differences may be explained by the nature of induced lesions. DNA breaks quickly appear and can be repaired unlike micronuclei that require cell division, correspond to persistent lesions as non-repairable.

Disjunction between aneuploidies and micronucleus formation were described with other types of pesticides. Genotoxicity studies on organosulfite acaricide and dicarboximide fungicide have shown a lack of activity for both compounds in inducing chromosomal aberrations and SCEs. In contrast, both pesticides significantly increased micronucleus frequency [40]. The aneuploidy-inducing activity of alachlor and dichlorvos, two pesticides representing an important source of human exposure to potential carcinogens, has been evaluated in a cytokinesis block micronucleus assay combined with anti-kinetochore staining to detect chromosome loss and in situ hybridization with chromosome-specific centromeric probes for the analysis of non-disjunction. The two pesticides differed in their mode of action; alachlor induced both chromosomal aberrations and aneuploidy, while the genotoxic activity of dichlorvos was only related to aneuploidy induction [41]. Another pesticide, rotenone, produced DNA damage and was cytotoxic during all phases of the cell cycle. Its clastogenicity was only limited to exposures made during the G1/S and S phases [42].

Several authors have described the alteration of chromosome numbers by environmental aneuploidy-inducing agents that induce microtubule and kinetochore disorganization in mitotic cells $[43,44]$. A distinction to be made between micronucleus induction due to chromosomal breakage and that obtained as a result of spindle disturbances. Our data show presence of high frequencies of lagging chromosomes after exposure to the lower concentrations of pesticide. The presence of lagging chromosomes is an indication of anti-microtubule activities of the pesticides tested, as describe for other pesticides [43], but the decrease of aneuploidies quicker than mitotic index decrease as increase of micronuclei is shown, allow to do a distinction of different sulcotrione targets during cell division (Table 1). Smaller chromosomal breakages would lead to micronucleus increase along with sulcotrione concentrations, then showing a decrease of mitotic index. Our results also corroborate the documented micronucleus formation in animal cells containing chromosomal aberrations induced by exposure to genotoxic agents $[16,45]$.

In conclusion, this is the first report of the genotoxic effect of sulcotrione, a triketone herbicide, on plants, resulting in the appearance of micronuclei and abnormalities of mitosis.

\section{Acknowledgment}

This work was supported by a grant from French agency ANR "ECOPHYTO". We thank Céline Sac for her skillful assistance and Dr. Boris Fumanal for his helpful comments on the manuscript.

\section{References}

11] A. Schulz, O. Ort, P. Beyer, H. Kleinig, SC-0051, a 2-benzoyl-cyclohexane-1, 3 dione bleaching herbicide, is a potent inhibitor of the enzyme phydroxyphenylpyruvate dioxygenase, FEBS Lett. 318 (1993) 162-166.

[2] J. Secor, Inhibition of barnyardgass 4-hydroxyphenylpyruvate dioxygenase by sulcotrione, Plant Physiol. 106 (1994) 1429-1433.

[3] T. Soeda, T. Uchida, Inhibition of pigment synthesis by 1, 3-dimethyl-4-(2, 4dichlorobenzoyl)-5-hydroxypyrazole, norflurazon, and new herbicidal compounds in radish and flatsedge plants, Pestic. Biochem. Physiol. 29 (1987) 35-42.

[4] D.J. Mayonado, K.K. Hatzios, D.M. Orcutt, H.P. Wilson, Evaluation of the mechanism of action of the bleaching herbicide SC -0051 by HPLC analysis, Pestic. Biochem. Physiol. 35 (1989) 138-145.

[5] R.A. Wichert, J.K. Townson, D.W. Bartlett, G.A. Foxon, Technical review of mesotrione, a new maize herbicide, In Proc. Brighton Crop Prot. Conference. Weeds, BCPC, Farnham, Surrey, UK, Vols 1-3, 1999, pp. 105-110.

[6] R. Cherrier, C. Perrin-Ganier, M. Schiavon, Degradation of sulcotrione in a brown soil amended with various organic matters, Agronomie 24 (2004) 29-33.

[7] R. Cherrier, A. Boivin, C. Perrin-Ganier, M. Schiavon, Sulcotrione versus atrazine transport and degradation in soil columns, Pest Manage. Sci. 61 (2005) 899904.

[8] J.S. Kim, T.J. Kim, O.K. Kwon, K.Y. Cho, Mechanism of action of sulcotrione, a 4hydroxyphenylpyruvate dioxygenases inhibitor, in developed plant tissue, Photosynthetica 40 (2002) 541-545.

[9] H. Chaabane, J.F. Cooper, L. Azouzi, C.M. Coste, Influence of soil properties on the adsorption-desorption of sulcotrione and its hydrolysis metabolites on various soils, J. Agric. Food Chem. 53 (2005) 4091-4095.

[10] A. Ter Halle, D. Drncova, C. Richard, Phototransformation of the herbicide sulcotrione on maize cuticular wax, Environ. Sci. Technol. 40 (2006) 2989-2995.

[11] H. Chaabane, E. Vulliet, F. Joux, F. Lantoine, P. Conan, J.F. Cooper, C.M. Coste, Photodegradation of sulcotrione in various aquatic environments and toxicity of its photoproducts for some marine micro-organisms, Water Res. 41 (2007) 1781-1789.

[12] J.L. Bonnet, F. Bonnemoy, M. Dusser, J. Bohatier, Toxicity assessment of the herbicides sulcotrione and mesotrione toward two reference environmental microorganisms: Tetrahymena pyriformis and Vibrio fischeri, Arch. Environ. Contam. Toxicol. 55 (2008) 576-583.

[13] B. Eyheraguibel, C. Richard, G. Ledoigt, A. Ter Halle, Photoprotection by plant extracts: a new ecological means to reduce pesticide photodegradation, J. Agric. Food Chem. 58 (2010) 9692-9696.

[14] B. Eyheraguibel, C. Richard, G. Ledoigt, A. Ter Halle, Inhibition of Herbicide Photodegradation by Plant Products, J. Agric. Food Chem. 59 (2011) 48684873.

[15] W.F. Grant, E.T. Owens, Chromosome aberration assays in Crepis for the study of environmental mutagens, Mutat. Res. 410 (1998) 291-307.

[16] G. Krishna, M. Hayashi, In vitro rodent micronucleus assay: protocol, conduct and data interpretation, Mutat. Res. 455 (2000) 155-166.

[17] S. Türkoglu, Genotoxicity of five food preservatives tested on root tips of Allium cepa L, Mutat. Res. 626 (2007) 4-14.

[18] D. Souguir, E. Ferjani, G. Ledoigt, P. Goupil, Exposure of Vicia faba and Pisum sativum to copper-induced genotoxicity, Protoplasma 233 (2008) 203-207.

[19] T. Çava, S. Ergene-Gözükara, Micronuclei, nuclear lesions and interphase silver-stained nucleolar organizer regions (AgNORs) as cyto-genotoxicity indicators in Oreochromis niloticus exposed to textile mill effluent, Mutat. Res. 538 (2003) 81-91.

[20] M.T. Llorente, A. Martos, A. Castano, Detection of cytogenetic alterations and blood cell changes in natural populations of carp, Ecotoxicology 11 (2002) 2734.

[21] T. Çava, S. Ergene-Gözükara, Genotoxicity evaluation of metronidazole using the piscine micronucleus test by acridine orange fluorescent staining, Environ. Toxicol. Pharmacol. 19 (2005) 107-111.

[22] L. Marcano, M.H. Carruyo, A. Del Campo, A. Montiel, Cytotoxicity and mode of action of maleic hydrazide in root tips of Allium Cepa L, Environ. Res. 94 (2004) 221-226. 
[23] P. Goupil, D. Souguir, E. Ferjani, G. Ledoigt, Sequential effects of cadmium on genotoxicity and lipoperoxidation in Vicia faba roots, Ecotoxicology 20 (2011) 329-336.

[24] A.S. Foltête, A. Dhyèvre, J.F. Férard, S. Cotelle, Improvement of Viciamicronucleus test for assessment of soil quality: A proposal for international standardization, Chemosphere 85 (2011) 1624-1629.

[25] G. Mac Kinney, Absorption of light by chlorophyll solution, J. Biol. Chem. 140 (1941) 315-322.

[26] D.I. Arnon, Copper enzymes in isolated chloroplasts, Plant. Physiol. 24 (1949) $1-15$.

[27] R.R. Sokal, F.J. Rohlf, Biometry: the principles and practice of statistics, in: Biological Research, 2nd ed., W. H. Freeman and Co, New York, 1981.

[28] D.J. de Kergommeaux, W.F. Grant, S.S. Sandhu, Clastogenic and physiological response of chromosomes to nine pesticides in the Vicia faba in vivo root tip assay system, Mutat. Res. 124 (1983) 69-84.

[29] H. Chabaane, E. Vulliet, R. Calvayrac, C.M. Coste, J.F. Cooper, Behaviour of sulcotrione and mesotrione in two soils, Pest Manag. Sci. 64 (2008) 86-93.

[30] J. Rouchaux, O. Neus, H. Helen, R. Bulcke, Mobily and adsorption of the triketone herbicide mesotrione in the soil of corn crops, Toxicol. Environ. Chem. 79 (2001) 211-222.

[31] J.S. Wilson, C.L. Foy, Influence of Various Soil Properties on the Adsorption and Desorption of ICIA-0051 in Five Soils, Weed Technol. 6 (1992) 583586.

[32] J. Dyson, S. Beulke, C. Brown, M. Lane, Adsorption and degradation of the weak acid mesotrione in soil and environmental fate implications, J. Environ. Quality 31 (2002) 613-618.

[33] T.H. Ma, Z. Xu, C. Xu, H. McConnell, E.V. Rabago, G.A. Arreola, H. Zhang, The improved Allium/Vicia root tip micronucleus assay for clastogenicity of environmental pollutants, Mutat. Res. 334 (1995) 185-195[33].

[34] R. Kontek, R. Osiecka, B. Kontek, Clastogenic and mitodepressive effects of the insecticide dichlorvos on root meristems of Vicia faba, J. Appl. Genet. 48 (2007) 359-361.

[35] C. Russo, L. Rocco, A.M. Morescalchi, V. Stingo, Assessment of environmental stress by micronucleus, test and the comet assay on the genome of teleost populations from two natural environments, Ecotoxicol. Environ. Safety 57 (2004) 168-174.

[36] G.I. Klobucar, M. Pavlica, R. Erben, D. Papes, Application of the micronucleus and comet assays to mussel Dreissena polymorpha haemocytes for genotoxicity monitoring of freshwater environments, Aquatic Toxicol. 64 (2003) 15-23.

[37] W.H.M Siu, J. Cao, R.W. Jack, R.S.S. Wu, B.J. Richardson, L. Xu, P.K.S. Lam Application of the comet and micronucleus assays to the detection of B[a]P genotoxicity in haemocytes of the green-lipped mussel (Perna viridis), Aquatic Toxicol. 66 (2004) 381-392.

[38] V. Bombail, D. Aw, E. Gordon, J. Batty, Application of the comet and micronucleus assays to butterfish (Pholis gunnellus) erythrocytes from the Firth of Forth, Scotland, Chemosphere 44 (2001) 383-392.

[39] A. Hartmann, A. Elhajouji, E. Kiskinis, F. Poetter, H.J. Martus, A. Fjallman, W. Frieauff, W. Suter, Use of the alkaline comet assay for industrial genotoxicity screening: comparative investigation with the micronucleus test, Food Chem. Toxicol. 39 (2001) 843-858.

[40] P. Gadeva, B. Dimitrov, Genotoxic effects of the pesticides Rubigan, Omite and Rovral in root-meristem cells of Crepis capillaris L., Mutat. Res., Genet. Toxicol. Environ. Mutagen. 652 (2008) 191-197.

[41] M. Mattiuzzo, M. Fiore, R. Ricordy, F. Degrassi, Aneuploidy-inducing capacity of two widely used pesticides, Carcinog. 27 (2006) 2511-2518.

[42] P.D. de Lima, E.S. Yamada, E.T. da Costa, C do O. Pessoa, S.H. Rabenhorst, M de O. Bahia, P.C. Cardoso, R.A. Santos, M.deA. Cardoso Smith, R.R. Burbano, Genotoxic effects of rotenone on cultured lymphocytes, Genet. Mol. Res. 4 (2005) 822-831.

[43] G. Voutsinas, F.E. Zarani, A. Kappas, The effect of environmental aneuploidyinducing agents on the microtubule architecture of mitotic meristematic root cells in Hordeum vulgare, Cell Biol. Int. 21 (1997) 411-418.

[44] A.I. Seoane, F.N. Dulout, Genotoxic ability of cadmium, chromium and nicke salts studied by kinetochore staining in the cytokinesis-blocked micronucleus assay, Mutat. Res. 490 (2001) 99-106.

[45] G. Iarmarcovai, A. Botta, T. Orsière, Number of centromeric signals in micronuclei and mechanisms of aneuploidy, Toxicol. Lett. 166 (2006) 1-10. 